\title{
Hyperparasitism of the cryptoniscid isopod Liriopsis pygmaea on the lithodid Paralomis granulosa from the Beagle Channel, Argentina
}

\author{
Gustavo A. Lovrich ${ }^{1, *}$, Daniel Roccatagliata ${ }^{2}$, Laura Peresan ${ }^{2}$ \\ ${ }^{1}$ Consejo Nacional de Investigaciones Científicas y Técnicas, Centro Austral de Investigaciones Científicas (CADIC) CC 92, \\ V9410BFD Ushuaia, Tierra del Fuego, Argentina \\ ${ }^{2}$ Departamento de Biodiversidad y Biología Experimental, Facultad de Ciencias Exactas y Naturales, \\ Universidad de Buenos Aires, Ciudad Universitaria, C1428EHA Buenos Aires, Argentina
}

\begin{abstract}
A total of 29570 false king crab Paralomis granulosa were sampled from the Beagle Channel (5451' S, 68 12' W), Tierra del Fuego, Argentina, between July 1996 and August 1998. Crab size varied from 6.8 to $111.2 \mathrm{~mm}$ carapace length (CL). A few crabs parasitized by the rhizocephalan Briarosaccus callosus were found; prevalences of externae (the rhizocephalan reproductive body) and scars (the mark left on the host after the death of the parasite) were 0.28 and $0.16 \%$, respectively. Of 85 externae examined, 55 were non-ovigerous and 30 ovigerous. The cryptoniscid isopod Liriopsis pygmaea infested $36.5 \%$ of the B. callosus examined. The most abundant stage was the cryptonicus larva, accounting for 208 of the 238 L. pygmaea recovered. Cryptonisci showed a highly aggregated distribution. A total of $92.7 \%$ of cryptonicsci were recovered inside empty externae, suggesting that the latter were attractive to cryptonisci. Early subadult females of L. pygmaea were rare; only 3 individuals occurred inside 1 ovigerous externa. Eight late subadult and 18 adult females were found on 3 and 7 non-ovigerous externae, respectively; in addition, 1 aberrant late subadult was found on 1 ovigerous externa. In the Beagle Channel, the population of $P$. granulosa harbours 3 different parasites: the bopyrid isopod Pseudione tuberculata, which reaches highest prevalence at 10 to $20 \mathrm{~mm} \mathrm{CL}$, the rhizocephalan B. callosus, with highest prevalence at 20 to $40 \mathrm{~mm}$ CL, and the cryptoniscid isopod L. pygmaea, which mainly infests rhizocephalan on crabs $>40 \mathrm{~mm}$ CL.
\end{abstract}

KEY WORDS: Epicaridea · Rhizocephala $\cdot$ King crab · Briarosaccus callosus · Magellan Region · Subantarctic

Resale or republication not permitted without written consent of the publisher

\section{INTRODUCTION}

The false king crab Paralomis granulosa currently constitutes the main commercial shellfish in coastal waters of southern South America, chiefly in the Strait of Magellan and the Beagle Channel. Although basic biological information required for fishery management of P. granulosa is available (Lovrich \& Vinuesa 1999), knowledge of its parasites and their potential effects is limited (Hoggarth 1990, Roccatagliata \& Lovrich 1999).
The rhizocephalan Briarosaccus callosus has been reported worldwide on lithodid crab species (Pohle 1992b). In the southern hemisphere, B. callosus was found infesting Lithodes santolla, Paralomis granulosa, and $P$. spinosissima. The infested specimens of P. granulosa and L. santolla were collected in the Strait of Magellan, Beagle Channel and Malvinas (Falkland) Islands (Boschma 1962, Stuardo \& Solís 1963, Campodonico et al. 1983, Vinuesa 1989, Hoggarth 1990, Roccatagliata \& Lovrich 1999), whereas those of P. spinosissima were found exclusively in the South Georgia 
Islands area (Basson 1994, Otto \& MacIntosh 1996, Watters 1998). Otto \& MacIntosh (1996) suggested that infested crabs from the South Georgia Islands identified by Boschma (1962) as Lithodes antarcticus (= L. santolla) probably belong to $P$. spinosissima.

Several authors reported the occurrence of isopod hyperparasites in lithodids infested by the rhizocephalan Briarosaccus callosus from the Crozet Islands, South Georgia Islands and Canadian Atlantic waters, but none of them identified these specimens (Boschma 1962, Arnaud \& Do-Chi 1977, Pohle 1992a,b, Otto \& MacIntosh 1996, Watters 1998). While examining commercial catches of the false king crab Paralomis granulosa, taken from the Beagle Channel from 1996 to 1998, we found some B. callosus infested by 1 or more isopod epicarid each. We have identified and redescribed this hyperparasite as Liriopsis pygmaea (Peresan \& Roccatagliata 2004).

Liriopsis spp. are cryptoniscid isopods that parasitize rhizocephalan barnacles. They are protandric hermaphrodites, i.e. they are functional males when young and later change into females. Ovigerous females lose their isopod appearance and become a sac, with neither segmentation nor appendages, and die after expelling the larvae (Caullery 1908).

The biology of Liriopsis spp. is poorly documented. Caullery (1908) presented a comprehensive study of L. monophthalma, a hyperparasite of the rhizocephalan Peltogaster curvatus in the Bay of Naples, Italy. Because Liriopsis infestations are rare, we present data on the biology of L. pygmaea, a parasite of the rhizocephalan Briarosaccus callosus from the Beagle Channel. were caught with tangle nets of $40 \mathrm{~mm}$ mesh at 10 to $16 \mathrm{~m}$ depth in December 1996.

The CL of all sampled crabs was measured with a dial caliper to the nearest $0.1 \mathrm{~mm}$ according to Lovrich \& Vinuesa (1993). Those Paralomis granulosa showing externae or scars (indicative of lost externae) of the rhizocephalan Briarosaccus callosus were taken alive to the laboratory and fixed whole in $5 \%$ formalin-seawater. Each crab was classified into one of the following infestation categories: (1) infested by rhizocephalan: crabs with 1 to 2 externae attached to the soft ventral side of the abdomen; (2) rhizocephalan-scarred: crabs showing a dark rounded mark on the softer ventral side of the abdomen, indicative of a lost rhizocephalan externa; and (3) uninfested: crabs with neither externae nor scar evidence of past infestations by Briarosaccus callosus.

We considered that a false king crab was parasitized by Briarosaccus callosus when it had an externa in a position normally occupied by the egg mass of the host. However, this procedure does not account for those crabs infested by rhizocephalans in an early stage of development, i.e. those infested crabs in which the externa has not emerged yet. A hyperparasitized false king crab is easily recognizable when it carries mature females of Liriopsis pygmaea, which appear as bulbous sacs affixed to the mantle of rhizocephalan externa (see Fig. 1). However, immature stages of the hyperparasite are located within the rhizocephalan mantle cavity, and found only after dissection.

In the laboratory, Briarosaccus callosus externae were carefully removed from the crabs. The projection of the

\section{MATERIALS AND METHODS}

A total of 29570 specimens of Paralomis granulosa were collected in the Beagle Channel $\left(54^{\circ} 51^{\prime} \mathrm{S}, 68^{\circ} 12^{\prime} \mathrm{W}\right)$, Tierra del Fuego, Argentina. Crabs $>50 \mathrm{~mm}$ carapace length (CL) were captured with commercial conical traps between 10 and $50 \mathrm{~m}$ depth in July, September, October and December 1996, January, March, May, July and October 1997, and March, June, August and October 1998. During each survey, samples ranging from 924 to 3220 crabs were inspected for parasites. Crabs $<30 \mathrm{~mm}$ CL were collected by SCUBA at 8 to $10 \mathrm{~m}$ depth near the Bridges Islands $\left(54^{\circ} 51.0^{\prime} \mathrm{S}, 68^{\circ} 14.5^{\prime} \mathrm{W}\right)$, in August 1996 and February 1997. They were found inside crevices or hydrozoan colonies, and under rocks (Lovrich \& Vinuesa 1995). Most crabs between 30 and $50 \mathrm{~mm}$ CL

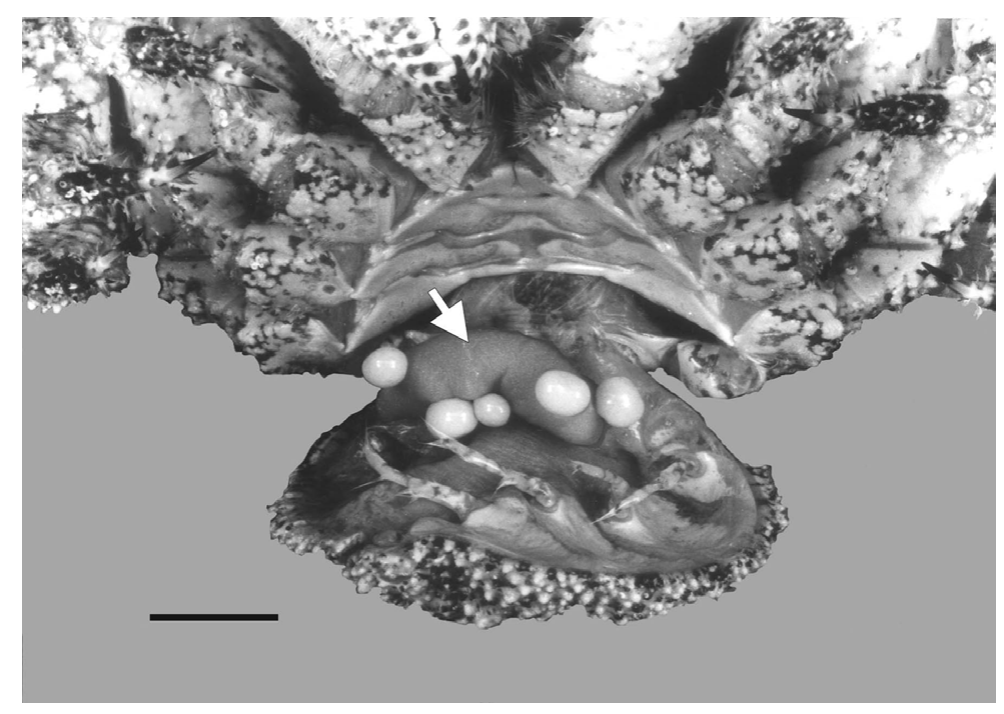

Fig. 1. Paralomis granulosa parasitized by Briarosaccus callosus hyperparasitized by Liriopsis pygmaea. Ventral view of a P. granulosa (68 mm carapace length, CL) with exposed abdomen showing an externa of B. callosus (arrow) infested by 6 late subadult females of L. pygmaea (one of them behind the externae, not observed in the photograph). Scale bar $=20 \mathrm{~mm}$ 
silhouette of the externa on a plane (area of externa: AE) was measured with an image analyzer Leica Quantimet 520. Under the stereomicroscope, the outer surface of the externa was inspected for cryptonisci, and after that the externa was dissected longitudinally with fine scissors. Adults and late subadult females of Liriopsis pygmaea were carefully detached from the outer wall of the externa, and early subadult females and cryptonisci were recovered from the mantle cavity. All of the hyperparasites were preserved in $70 \%$ ethanol.

Like other Peltogastridae, Briarosaccus callosus has a cuticular shield showing concentric rings or annuli, each indicating 1 molt (Lützen 1987). Under the stereomicroscope, the wall surrounding the stalk of the externa was cut with fine scissors and its outer cuticle detached with forceps from the epidermis. The removed piece of cuticle was cleaned with a small brush, mounted to a concave slide with glycerin, and sealed with a cover glass. The number of annuli was counted under a transmitted light microscope.

Individuals of the hyperparasite Liriopsis pygmaea were enumerated and classified according to Peresan \& Roccatagliata (2004) as follows:

Cryptoniscus larva (Fig. 2A): Body fusiform and segmented, with holdfast peraeopods and swimming pleopods. Inhabiting the inside mantle cavity, occasion-

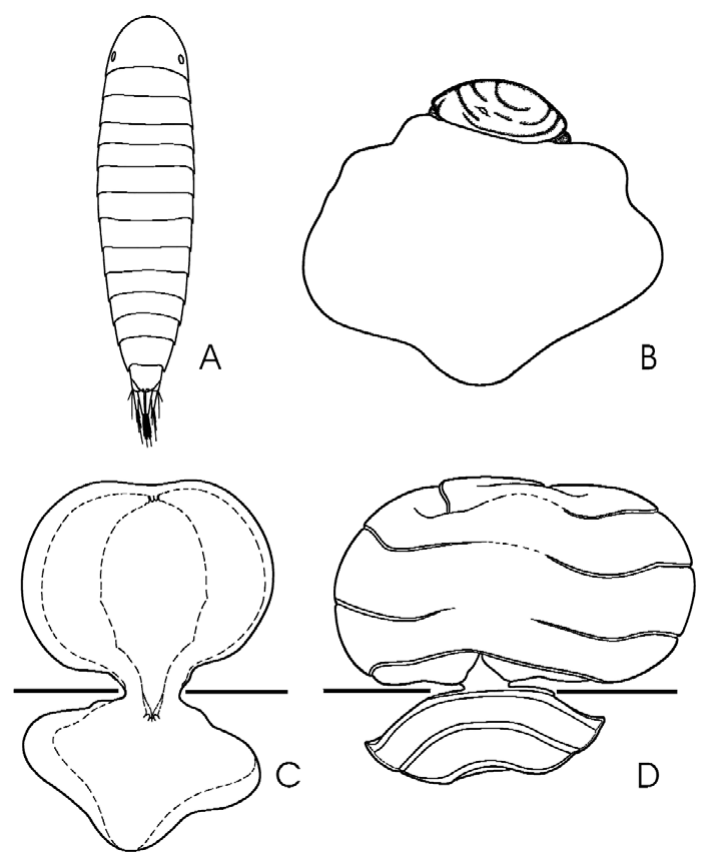

Fig. 2. Liriopsis pygmaea. Developmental stages: (A) cryptoniscus larva, (B) early subadult female, (C) advanced subadult female, (D) adult female. In (C) and (D), the bold horizontal line represents the mantle wall of the Briarosaccus callosus externa, upon which L. pygmaea is a parasite. Drawings are to different scales: cryptoniscus larvae are 1.4 to $1.5 \mathrm{~mm}$ length, the remaining stages vary from 3.3 to $9.7 \mathrm{~mm}$ length (see Peresan \& Roccatagliata 2004 for details) ally on the outer surface of the externa. Males differ from cryptoniscus larvae only in having mature testes, thus the term 'cryptoniscus larva' is used in this survey to refer to both stages (see also Nielsen \& Strömberg 1973).

Early subadult female (Fig. 2B): Body consisting of a large sac and a small flat disk, segmentation and appendages lost. Inhabiting the inside of the mantle cavity.

Late subadult female (Fig. 2C): Body divided by a constriction into a rhomboidal caudal portion embedded in the mantle cavity, and an anterior subspherical brood pouch freely exposed.

Adult female (Fig. 2D): Embedded portion of the body boat-shaped; subspherical brood pouch with a ventral slit through which larvae are released.

The externa of Briarosaccus callosus becomes greatly distended when the mantle cavity is filled with eggs (or embryos), and noticeably smaller after the release of nauplii (Bower \& Sloan 1985). Therefore, the relationship between the size of the externa and the size of the host crab was tested independently for both reproductive stages of the rhizocephalan (ANOVA, Sokal \& Rohlf 1995). Fisher's Exact test was used to analyze whether Liriopsis pygmaea was equally distributed between ovigerous and non-ovigerous externae of $B$. callosus. The frequency distribution of the number of individuals of $L$. pygmaea per externa of B. callosus was compared with a Poisson model (Elliot 1977).

\section{RESULTS}

\section{Infestation of Briarosaccus callosus on Paralomis granulosa}

Out of 29570 false king crab Paralomis granulosa sampled in the Beagle Channel, the prevalences of externae and scars of the rhizocephalan Briarosaccus callosus were very low: 0.28 and $0.16 \%$, respectively. B. callosus infested P. granulosa measuring 19.7 to $79.4 \mathrm{~mm}$ CL (Figs. 3 \& 4). Seven double infestations of B. callosus were observed, 4 on crabs measuring 24 to $26.9 \mathrm{~mm} \mathrm{CL}$, and 3 on crabs of 37.3 to $47.6 \mathrm{~mm} \mathrm{CL}$. Besides the double infestation, these last $3 \mathrm{crabs}$ each showed a scar (indicative of former infestation). A simultaneous infestation with an externa and a scar was observed in a crab measuring $39.0 \mathrm{~mm}$ CL.

Prevalences of externae and scars of Briarosaccus callosus peaked at different host sizes (Fig. 3). The prevalence of externae was highest (ca. 10\%) at 20 to $39.9 \mathrm{~mm} \mathrm{CL}$, whereas the prevalence of scars was highest $(1.05 \%)$ at 40 to $49.9 \mathrm{~mm} \mathrm{CL}$; both of which gradually declined thereafter. Scars were more frequent than externae at host size-classes > $60 \mathrm{~mm}$ CL.

The area of the externa (AE) was positively correlated with CL of Paralomis granulosa (Fig. 4), an indi- 


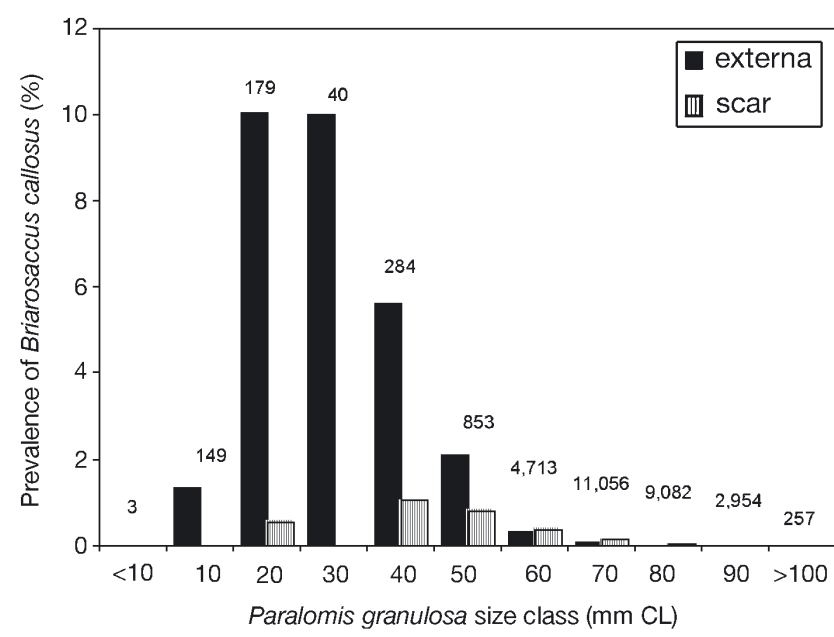

Fig. 3. Briarosaccus callosus parasitic upon Paralomis granulosa. Prevalence (\%) of externa or scar of B. callosus infesting various size classes of $P$. granulosa in the Beagle Channel, Argentina. Numbers at the top of the bars indicate the total number of crabs examined for each size class. Size classes are represented by their inferior limit, e.g. $10 \mathrm{~mm}$ carapace length (CL) corresponds to the size class of 10 to $19.9 \mathrm{~mm} \mathrm{CL}$. Crabs with simultaneous externa and scar (4 in total) were arbitrarily assigned to the category 'externa'

cation that new infestations occur on young crabs, after which parasite and host grow together. However, since externae with eggs (or nauplii) are distended, the slope of the regression line for ovigerous externae was greater than that for non-ovigerous externae (ANOVA $F=30.2 ; \mathrm{p} \ll 0.001$ ). Linear regressions were as follows: $\mathrm{AE}_{\text {ovigerous }}=11.2 \times \mathrm{CL}-$ $222.5\left(F_{\text {regression }}=154.2 ; \mathrm{p} \ll 0.001 ; \mathrm{R}^{2}=0.84\right)$; $\mathrm{AE}_{\text {non-ovigerous }}=6.0 \times \mathrm{CL}-128.5\left(F_{\text {regression }}=\right.$ $\left.187.2 ; \mathrm{p} \ll 0.001 ; \mathrm{R}^{2}=0.76\right)$. The smallest ovigerous externa was approximately 20.6 $\mathrm{mm}^{2}$.

The stalk of each externa was surrounded by a strong shield, which showed very distinct and clearly separated annuli. The number of annuli ranged from 1 to 69 in the 65 specimens counted, indicating that the rhizocephalan molted up to 69 times after the extrusion of the externa.

\section{Hyperparasitism of Liriopsis pygmaea on Briarosaccus callosus}

Of the 85 externae of Briarosaccus callosus examined, 31 (36.5\%) were infested by 1 or more stages of Liriopsis pygmaea. Hyperparasites occurred on $B$. callosus externae that measured from 77.5 to $621.4 \mathrm{~mm}^{2} \mathrm{AE}$ (Figs. 4
\& 5). The maximum prevalence of L. pygmaea $(75 \%)$ was recorded for the host externae size class of 200 to $299 \mathrm{~mm}^{2}$ AE (Fig. 5). Infested externae $<100 \mathrm{~mm}^{2}$ AE hosted only cryptonisci. The remaining size classes of $B$. callosus included both cryptonisci and female stages.

The cryptoniscus larva was the most abundant stage to infest externae. Of the 238 Liriopsis pygmaea recovered, 208 were cryptonisci (Table 1). Of these, 193 $(92.7 \%)$ were found inside the mantle cavity of Briarosaccus callosus; only 11 (5.7\%) were attached to the outer surface of the externa. Of these 11 cryptonisci, 5 were attached to non-ovigerous externae and 6 to ovigerous externae (Table 2, Fig. 4). However, an imprecise number of cryptonisci could have become detached from the outer surface of externae during sampling or fixation of the material, and hence, the abundance of cryptonisci may have been underestimated. The location data of 4 cryptonisci from an ovigerous externae were lost, and therefore it was not possible to determine whether they were on the mantle cavity or on the outer wall of the externa (Table 2, Fig. 4). Early subadult females were rare; only 3 individuals were found, all of them on 1 ovigerous externa. A total of 9 late subadult females and 18 adult females were found on 4 and 7 non-ovigerous externae, re-

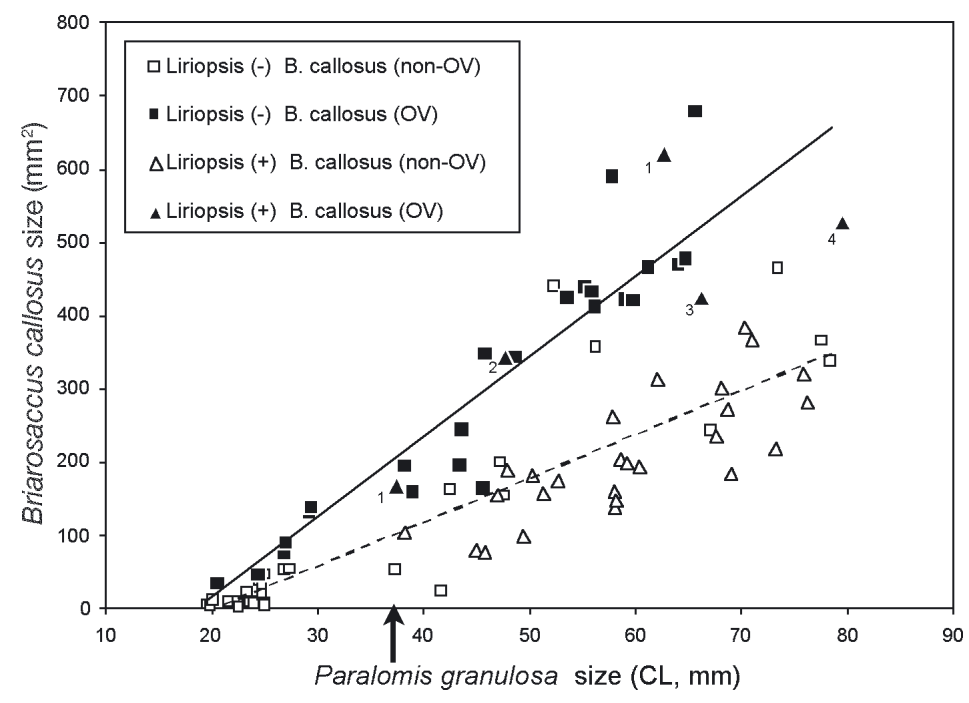

Fig. 4. Paralomis granulosa parasitized by Briarosaccus callosus hyperparasitized by Liriopsis pygmaea. Area of the externa of B. callosus (AE) in relation to the size of $P$. granulosa (carapace length, CL). Data are sorted according to whether $B$. callosus externae are ovigerous $(\mathrm{OV})$ or non-ovigerous (non-OV), and whether $L$. pygmaea is infesting the $B$. callosus externae or not. Solid line: regression line for ovigerous externae; dashed line: non-ovigerous externae. Double infestations are included as independent observations. The arrow indicates the size of the smallest infested $P$. granulosa (38.1 mm CL). Numbers below black triangles: (1) cryptonisci clinging to the outer surface of the externa, (2) cryptonisci of uncertain location, (3) 3 early subadult females, and (4) 1 abnormal late subadult female 
Table 1. Liropsis pygmaea parasitic upon Briarosaccus callosus. Frequency of the developmental stages of $L$. pygmaea and the position of cryptonisci on the externa of $B$. callosus. Numbers are quantity of externae infested (from total $\mathrm{N}=31$ ). The total number of cryptonisci is given in parentheses

\begin{tabular}{|c|c|c|c|c|c|c|}
\hline & \multirow{2}{*}{$\begin{array}{l}\text { Position of } \\
\text { cryptonisci on } \\
\text { externa }\end{array}$} & \multicolumn{5}{|c|}{ Liriopsis pygmaea stages - } \\
\hline & & $\begin{array}{l}\text { Cryptonisci } \\
\text { only }\end{array}$ & $\begin{array}{l}\text { Early subadult } \\
\text { females }\end{array}$ & $\begin{array}{l}\text { Late subadult } \\
\text { females }\end{array}$ & $\begin{array}{c}\text { Adult } \\
\text { females }\end{array}$ & Total \\
\hline $\begin{array}{l}\text { Rhizocephalans } \\
\text { without cryptonisci }\end{array}$ & & - & 1 & 2 & - & 3 \\
\hline Rhizocephalans & Internal & $14(110)$ & - & $2(2)$ & $6(72)$ & $22(184)$ \\
\hline with cryptonisci & External & $2(6)$ & - & - & $1(1)$ & $3(7)$ \\
\hline & Internal and external & $2(13)$ & - & - & - & $2(13)$ \\
\hline & Indeterminate & $1(4)$ & - & - & - & $1(4)$ \\
\hline
\end{tabular}

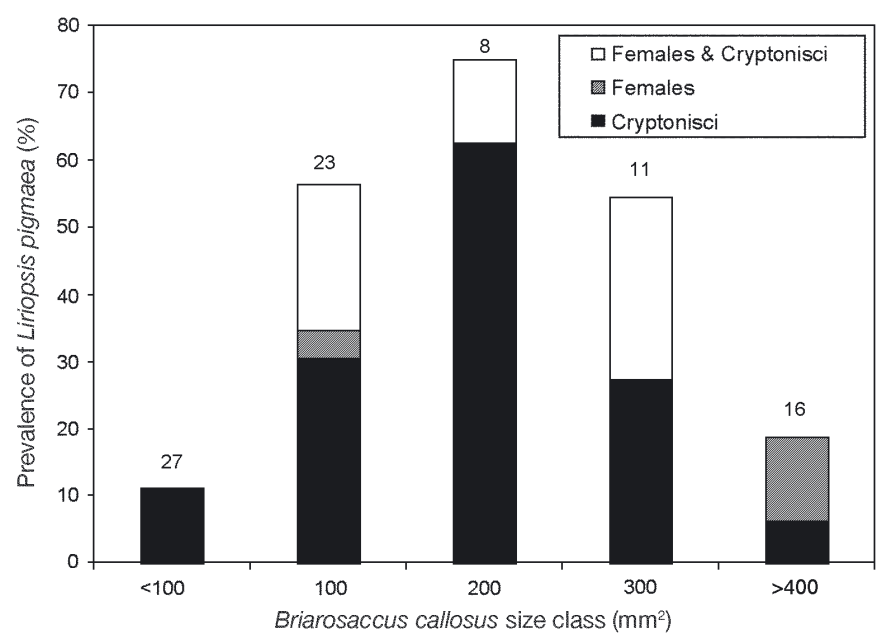

Fig. 5. Liropsis pygmaea parasitic upon Briarosaccus callosus. Prevalence of $L$. pygmaea in relation to $B$. callosus externa area (AE). Numbers at the top of the bars indicate the number of $B$. callosus for each size class. The category 'females' includes early and late subadult females, and adult females. Size classes are represented by their inferior limit, e.g. $100 \mathrm{~mm}^{2} \mathrm{AE}$ corresponds to 100 to $199 \mathrm{~mm}^{2} \mathrm{AE}$

spectively. Adult females were always accompanied by cryptonisci (Table 1).

We investigated whether Liriopsis pygmaea was equally distributed between ovigerous and non-ovigerous Briarosaccus callosus (Table 2). Most of the externae infested by L. pygmaea were non-ovigerous. The observed frequency of infested ovigerous externae was significantly lower than expected (Fisher's Exact test, $\mathrm{p}=0.004$ ). A similar tendency was observed when the effect of the cryptonisci, or that of the females, was analyzed separately. However, for the latter, the null hypothesis was marginally non-significant (Fisher's Exact test, $\mathrm{p}=0.055$ ).
The frequency distribution of the number of individuals of Liriopsis pygmaea on each externa of Briarosaccus callosus was markedly aggregated (Fig. 6). When compared to a Poisson distribution, non-infested externae, and those with 6 or more individuals of $L$. pygmaea, were more frequent than expected, whereas externae with 1 to 5 individuals of L. pygmaea were fewer than expected (goodness of fit of Poisson $\chi^{2}=$ 518.8, $\mathrm{p} \ll 0.001)$. An extreme case was observed in 1 externa which had as many as 1 adult female and 46 cryptoniscus larvae of L. pygmaea.

\section{DISCUSSION}

The prevalence of Briarosaccus callosus was extremely low $(0.28 \%)$ in the false king crab Paralomis granulosa. This agrees with the generally low prevalence, i.e. 0.24 to $2.34 \%$, previously reported (Campodonico et al. 1983, Vinuesa 1989, Hoggarth 1990). In the Malvinas (Falkland) Islands, Hoggarth (1990) reported that the prevalence of externae was highest in crabs ranging from 30 to $39.9 \mathrm{~mm} \mathrm{CL}(3.2 \%$, calculated

Table 2. Liropsis pygmaea parasitic upon Briarosaccus callosus. Frequency of infestation of $L$. pygmaea in relation to the ovigerous condition of $B$. callosus. The category ' $L$. pygmaea present $(+)$ ' includes rhizocephalans infested by 1 or more L. pygmaea stages. The category 'cryptonisci' includes rhizocephalans infested exclusively by cryptoniscus larvae. (*) includes 1 externa with 3 early subadult females, and another with 1 aberrant older subadult female; ( 1 ) includes 2 externae with 1 and 5 cryptonisci that were clinging to their outer wall, respectively, and 1 externa with 4 cryptonisci of uncertain location

\begin{tabular}{|lccc|}
\hline & Briarosaccus callosus externa condition & $\begin{array}{c}\text { Fisher's } \\
\text { Exact test, } \mathrm{p}\end{array}$ \\
\hline Liriopsis pygmaea & Non-ovigerous & Ovigerous & \\
Absent (-) & 29 & 25 & \\
Present (+) & 26 & 5 & 0.004 \\
Females & 10 & $2\left(^{*}\right)$ & 0.055 \\
Cryptonisci & 16 & $3(\mathrm{I})$ & 0.016 \\
\hline
\end{tabular}




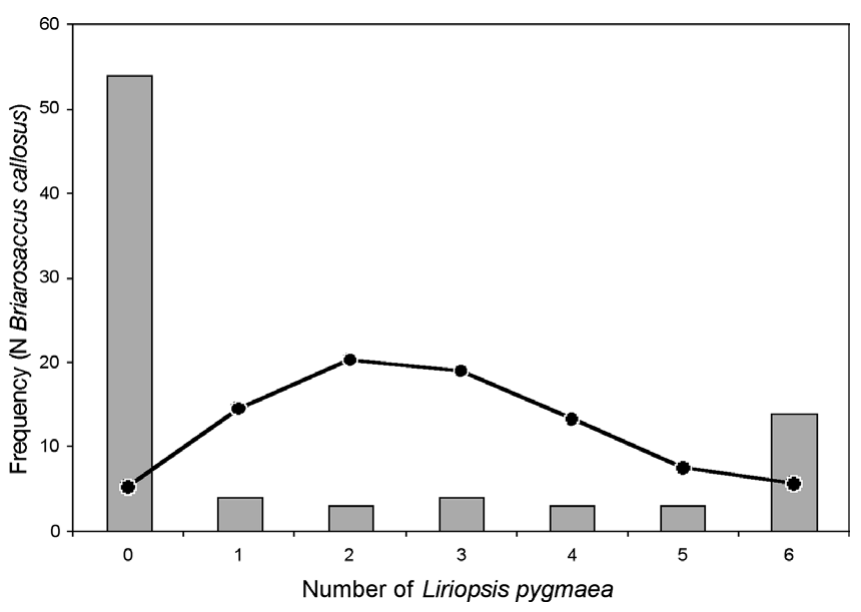

Fig. 6. Liropsis pygmaea parasitic upon Briarosaccus callosus. Poisson-fitted and actual frequency distribution of L. pygmaea infesting B. callosus. Observed (bars) and expected (line) frequencies of infestation of $B$. callosus externae by hyperparasite

from his Table II). In the Beagle Channel (present study), this rhizocephalan was also more prevalent among smaller crabs, i.e. prevalence peaked around $10 \%$ in the size classes 20 to 29.9 and 30 to $39.9 \mathrm{~mm} \mathrm{CL}$ (Fig. 3). Hoggarth (1990) did not observe infested crabs of 20 to $29.9 \mathrm{~mm} \mathrm{CL}$, likely because small crabs were scarcely represented in his samples. Although the prevalence of $B$. callosus externae was higher in the Beagle Channel than in the Malvinas (Falkland) Islands, both populations showed similar trends: a gradual decrease of infestation with crab size, and a higher prevalence of scars than externae among larger crabs.

Although the prevalence of Briarosaccus callosus was low, that of the hyperparasite Liriopsis pygmaea on B. callosus was moderately high (36.5\%). Otto \& MacIntosh (1996) reported a maximum prevalence of $15 \%$ of B. callosus on the lithodid crab Paralomis spinosissima around the South Georgia Islands. In turn, $26 \%$ of these rhizocephalans were infested by an isopod hyperparasite. These authors likely recorded the hyperparasites that were only attached to the outer surface of the externae and, therefore, underestimated the actual prevalence of the hyperparasite. In our study, the prevalence of externae with specimens of L. pygmaea fixed to their outer wall was as low as $13 \%$, that is, half of that presented by Otto \& MacIntosh (1996).

The internal cryptonisci of Liriopsis pygmaea were exclusively found in non-ovigerous externae. This fact suggests that the cryptonisci invade the externae when the latter are free of eggs or nauplii. Supporting this hypothesis was the highly aggregated distribution of cryptonisci, which may indicate a massive invasion during the short interval between the release of one batch of nauplii and the next oviposition. We did not recover any L. pygmaea that had just begun to metamorphose into females, but we found 3 early subadult females in a single externa containing thousands of eggs. Although this single case is insufficient to reach a conclusion, it suggests that the rhizocephalan can release at least 1 new batch of eggs into the mantle cavity after cryptonisci invasion. Further data are needed to confirm this preliminary observation.

All the examined externae that had female isopods of Liriopsis pygmaea attached to their outer wall (except 1 having an aberrant subadult female) were nonovigerous. This fact suggests a detrimental effect of L. pygmaea on the egg production of the rhizocephalan Briarosaccus callosus. Caullery (1908) also found ovigerous or spent female isopods attached to nonovigerous externa in Peltogaster curvatus infested by L. monophthalma. Caullery (1908) suggested that atrophy of the rhizocephalan ovary may occur during the intrapaleal female phase of L. monophthalma, and that sterilization is likely temporary, since the ovaries of $P$. curvatus recover after the death of the hyperparasite.

The isopod Liriopsis monophthalma has a life span of ca. 12 wk (Caullery 1908). Lützen (1987) counted 11 to 75 annuli on the cuticular shields of Briarosaccus callosus infesting Lithodes aequispinus from the Northeastern Pacific, and estimated that B. callosus may live as many as 9.4 yr. In the present study we recorded externae of $B$. callosus with up to 69 annuli. Assuming that the life span of Liriopsis pygmaea is much shorter than that of the B. callosus, and taking into account the fact that the prevalence of $L$. pygmaea was relatively high $(36.5 \%)$, we speculate that nearly all the population of B. callosus became hyperparasitized 1 or more times throughout their life span.

In addition to the rhizocephalan Briarosaccus callosus and the hyperparasite Liriopsis pygmaea, the false king crab Paralomis granulosa hosts a third parasite: the isopod bopyrid Pseudione tuberculata. This bopyrid lives in the left, and only rarely in the right, branchial chamber of the crab. These 3 parasites occur at disparate size classes in the population of the false king crab P. granulosa from the Beagle Channel. The prevalence of the bopyrid $P$. tuberculata was highest among crabs ranging from 10 to $20 \mathrm{~mm} \mathrm{CL}$ (Roccatagliata \& Lovrich 1999), whereas that of the rhizocephalan $B$. callosus was highest among crabs ranging from 20 to $40 \mathrm{~mm} \mathrm{CL}$ (Fig. 3). Moreover, the smallest crab carrying a rhizocephalan infested by L. pygmaea was $37.3 \mathrm{~mm}$ CL (Fig. 4). Crabs >60 mm CL are virtually free of parasitism. The only evidence of a past bopyrid or rhizocephalan infestation is a bulge on their carapaces or a scar under their abdomens, respectively. 
Acknowledgements. We are grateful to Pesquera del Beagle S.A. for allowing us to sample on board their fishing boats. Jeffrey Shields (Virginia Institute of Marine Sciences, USA) and Sven Thatje (Alfred Wegener Institute, Germany) and 2 anonymous reviewers provided useful comments on the manuscript. Martín Torres-Jordá (Universidad de Buenos Aires) provided assistance with statistics, and Gabriel Rosa (Universidad de Buenos Aires) helped with the image analyzer. This study was partially financed by the International Foundation for Sciences, Stockholm, Sweden (IFS A-2507/1), the Universidad de Buenos Aires (Grant X019) and the Consejo Nacional de Investigaciones Científicas y Técnicas, Argentina (CONICET).

\section{LITERATURE CITED}

Arnaud PM, Do-Chi T (1977) Données biologiques et biométriques sur les lithodes Lithodes murrayi (Crustacea: Decapoda: Anomura) des îles Crozet (SW océan Indien). Mar Biol 39:147-159

Basson M (1994) A preliminary investigation of the possible effects of rhizocephalan parasitism on the management of the crab fishery around South Georgia. CCAMLR Sci 1:175-192

Boschma H (1962) Rhizocephala. Discov Rep 33:55-92

Bower SM, Sloan NA (1985) Morphology of the externa of Briarosaccus callosus Boschma (Rhizocephala) and the relationship with its host Lithodes aequispina Benedict (Anomura). J Parasit 71:455-463

Campodonico I, Hernández MB, Riveros E (1983) Investigación, manejo y control de las pesquerías de centolla y centollón de la XII Región. Informe consolidado: recurso centollón. Inf Inst Patagonia, Punta Arenas (Chile) 25:1-97

Caullery M (1908) Recherches sur les Liriopsidae, Épicarides cryptonisciens parasites des Rhizocéphales. Mitt Zool Stat Neapel 18:583-643

Elliott JM (1977) Some methods for the statistical analysis of samples of benthic invertebrates. Freshw Biol Ass Sci Publ, No. 25

Hoggarth DD (1990) The effects of parasitism by rhizocephalan, Briarosaccus callosus Boschma on the lithodid crab, Paralomis granulosa (Jacquinot) in the Falkland Islands. Crustaceana 59:156-170

Lovrich GA, Vinuesa JH (1993) Reproductive biology of the false southern king crab (Paralomis granulosa, Lithodidae) in the Beagle Channel, Argentina. Fish Bull 91:664-675

Lovrich GA, Vinuesa JH (1995) Growth of immature false southern king crab, Paralomis granulosa (Anomura, Lithodidae), in the Beagle Channel, Argentina. Sci Mar 59: 87-94

Editorial responsibility: Timothy Flegel, Bangkok, Thailand
Lovrich GA, Vinuesa JH (1999) Reproductive potential of the lithodids Lithodes santolla and Paralomis granulosa in the Beagle Channel, Argentina. In: Arntz W, Ríos C (eds) Magellan-Antarctic: ecosystems that drifted apart. Sci Mar 63 (Suppl 1):355-360

Lützen J (1987) Life history parameters calculated from growth rings in parasitic barnacles of the family Peltogastridae (Crustacea: Cirripedia: Rhizocephala). J Crustac Biol 7:493-506

Nielsen SO, Strömberg JO (1973) Morphological characteristics of taxonomical importance in Cryptoniscina (Isopoda: Epicaridea). A scanning electron microscopic study of cryptoniscus larvae. Sarsia 52:75-96

Otto RS, MacIntosh RA (1996) Observations on the biology of the lithodid crab Paralomis spinosissima from the Southern Ocean near South Georgia. Proc Symp High Latitude Crabs: biology, management, and economics. Alaska Sea Grant Coll Prog Rep 96-02. Univ Alaska Fairbanks, p 627-647

Peresan L, Roccatagliata D (2004) First record and redescription of the hyperparasite Liriopsis pygmaea (Cryptoniscina, Isopoda) of the false king crab Paralomis granulosa from the Beagle Channel (Argentina). J Nat Hist (in press)

Pohle GW (1992a) First Canadian record of Paralomis bouvieri Hansen, 1908 (Decapoda: Anomura: Lithodidae), infected by the rhizocephalan Briarosaccus callosus (Cirripedia: Peltogastridae) and carrying a hyperparasitic cryptoniscid (Epicaridea). Can J Zool 70:1625-1629

Pohle GW (1992b) First record of the rhizocephalan Briarosaccus callosus (Cirripedia, Peltogastridae) infecting the Atlantic porcupine stone crab Neolithodes grimaldii (Decapoda, Anomura, Lithodidae). Crustaceana 62:133-136

Roccatagliata D, Lovrich GA (1999) Infestation of the false king crab Paralomis granulosa (Decapoda: Lithodidae) by Pseudione tuberculata (Isopoda: Bopyridae) in the Beagle Channel, Argentina. J Crustac Biol 19:720-729

Sokal RR, Rohlf FJ (1995) Biometry. The principles and practice of statistics in biological research. WH Freeman \& Co, San Francisco

Stuardo J, Solís I (1963) Biometría y observaciones generales sobre la biología de Lithodes antarcticus Jacquinot. Gayana (Zool) 11:1-49

Vinuesa JH (1989) Efectos e incidencia del parasitismo en la centolla (Lithodes santolla) y el centollón (Paralomis granulosa) del Canal de Beagle. Physis (A) 47:45-51

Watters G (1998) Prevalences of parasitized and hyperparasitized crabs near South Georgia. Mar Ecol Prog Ser 170: $215-229$

Submitted: December 11, 2002; Accepted: September 6, 2003 Proofs received from author(s): January 19, 2004 